\title{
Sosialisasi dan Pelatihan Mitigasi Bencana Guna Membangun Universitas Jenderal Achmad Yani sebagai Prototipe Kampus Siaga Bencana
}

\author{
Fransiska Ambarukmi P, Iis Inayati R, Djoni Kusuma P, \\ Yudith Yunia K, Andri A Rusman \\ Fakultas Kedokteran, Universitas Jenderal Achmad Yani, Cimahi \\ Penulis korespondensi : fransiska.ambarukmi@lecture.unjani.ac.id
}

\begin{abstract}
Abstrak: Program sosialisasi dan pelatihan mitigasi bencana bagi tenaga pengajar, kependidikan dan tenaga pendukung di lingkungan kampus Unjani ini bertujuan untuk meningkatkan pengetahuan dan kemampuan warga kampus mengenai sistem mitigasi bencana, karena mereka menghabiskan sebagian besar waktunya sehari-hari di kampus. Melalui program ini diharapkan warga kampus Unjani memahami bagaimana harus menyelamatkan diri dan menyelamatkan teman/masyarakat di sekitarnya pada saat terjadi bencana. Permasalahan yang dihadapi kampus Universitas Jenderal Achmad Yani adalah belum tersedia sistem mitigasi bencana, sebagian gedung administrasi dan perkuliahan belum dilengkapi dengan rambu dan tanda bahaya sebagai petunjuk evakuasi dan penyelamatan diri saat terjadi bencana, belum tersedia media edukasi dan informasi mengenai upaya kesiapsiagaan bencana bagi warga kampus dan masih rendahnya pengetahuan dan keterampilan warga kampus mengenai mitigasi bencana. Solusi yang ditawarkan untuk mengatasi permasalahan tersebut adalah pelatihan dan pendampingan warga kampus mengenai sistem mitigasi bencana, penyediaan alat, sarana dan prasarana tanda bahaya dan petunjuk evakuasi dan penyelamatan saat terjadi bencana, serta penyediaan media edukasi bagi warga kampus tentang sistem mitigasi bencana. Kegiatan ini mampu mengubah pola pandang dan sikap peserta pelatihan mengenai dasar manajemen bencana, sehingga pada akhirnya dapat menjadi langkah awal untuk menciptakan Universitas Jenderal Achmad Yani sebagai prototipe kampus yang tanggap dan siaga bencana.
\end{abstract}

Kata kunci: Bencana, Mitigasi, Siaga, Warga Kampus Unjani.

Abstract: The disaster mitigation socialization and training program for teaching, education and supporting staff at the Unjani campus aims to increase the knowledge and abilities of campus residents regarding the disaster mitigation system. It is hoped that the participants will understand how to save themselves and their community in the event of a disaster. The problems faced by the campus of Unjani are that there is no disaster mitigation system available. Some buildings are not equipped by danger signs as instructions for evacuation and self-rescue, and there is no educational media and information regarding disaster preparedness.There is the lack of knowledge and skills of participants regarding disaster mitigation. The solutions offered to overcome these problems are training and mentoring for campus residents regarding disaster mitigation systems, provision of tools, facilities and infrastructure for danger signs and instructions for evacuation and rescue in the event of a disaster, and providing educational media about disaster mitigation systems. This program was able to change the perspective and attitudes of the participants regarding the basics of

Volume 2, Nomor 2, Oktober 2021 | 86

Sosialisasi dan Pelatihan Mitigasi Bencana Guna Membangun Universitas Jenderal Achmad Yani sebagai

Prototipe Kampus Siaga Bencana

Fransiska Ambarukmi P, Iis Inayati R, Djoni Kusuma P, Yudith Yunia K, Andri A Rusman

https://doi.org/10.26874/jakw.v2i2.77 
disaster management, so that in the end it could be the first step to create Unjani as a campus prototype for disaster-responsive and preparedness.

Keywords: Disaster, Mitigation, Preparedness, Unjani Campus Residents.

\section{Pendahuluan}

Indonesia merupakan salah satu negara yang memiliki wilayah yang rentan terhadap bencana termasuk gempa bumi. Salah satu dampak dari gempa yang terjadi di Indonesia adalah kerusakan sarana dan prasarana bangunan, termasuk bangunan kampus, dan perkantoran yang mengakibatkan terganggunya proses pembelajaran dan administrasi di lingkungan kampus. Lebih dari 7.000 sekolah rusak berat akibat gempa dan tsunami sejak tahun 2004 (Wisner, 2015; Sapir, 2016; Rahma, 2018).

Dampak tersebut akan lebih parah jika bencana terjadi pada saat proses belajar-mengajar sedang berlangsung di kampus, karena reruntuhan bangunan dan benda sekitarnya dapat menimpa dan atau menimbun peserta didik, tenaga pengajar maupun tenaga kependidikan lainnya. Oleh karena itu, diperlukan lingkungan belajar yang dapat menjamin keamanan dan keselamatan warga sekolah siaga setiap saat termasuk dari ancaman bencana alam (Rahma, 2018; Guha-Sapir et al., 2010).

Sejalan dengan semangat untuk melindungi hak-hak anak atas perlindungan, keamanan dan kelangsungan hidup dan juga hak untuk mendapatkan pendidikan dasar yang berkualitas dan berkesinambungan, perlu dilakukan untuk dapat menyebarkan pengetahuan mengenai pengurangan risiko bencana berikut fasilitas sekolah yang aman dan manajemen bencana di sekolah melalui tenaga pendidik maupun fasilitator, salah satunya dengan membangun sistem mitigasi bencana serta menyusun modul yang dapat menjadi referensi bagi para pemangku kebijakan, dan warga kampus pada umumnya (Guha-Sapir et al., 2010; Putra, 2016; Torani, 2019).

Langkah pertama yang dilakukan adalah dengan memperkenalkan sistem mitigasi bencana yang mengacu pada Perka BNPB No. 4 tahun 2012 tentang Pedoman Penerapan Sekolah/Madrasah Aman Bencana terhadap Kerangka Kerja Sekolah Aman yang Komprehensif, di mana Kerangka Kerja ini dengan tiga pilarnya sudah disepakati oleh dunia internasional, khususnya UNISDR. Pemerintah Indonesia telah menetapkan Undang-Undang No. 24 Tahun 2007 tentang Penanggulangan Bencana yang menekankan bahwa Penanggulangan Bencana tidak hanya terpaku pada tahap tanggap darurat/ respons saja, tetapi 
juga mencakup tahap pra bencana (kesiapsiagaan) dan pasca bencana (pemulihan), di mana Undang-Undang tersebut secara jelas menyatakan bahwa setiap orang berhak mendapatkan pendidikan, pelatihan, penyuluhan, dan keterampilan dalam penyelenggaraan penanggulangan bencana, baik dalam situasi tidak terjadi bencana maupun situasi terdapat potensi bencana.Salah satu upaya yang dapat dilakukan dengan memastikan bahwa lingkungan pendidikan - sekolah dan fasilitas pendidikan - aman dari bencana dan bukan merupakan tempat yang dapat membahayakan kehidupan peserta didik, tenaga pengajar dan tenaga kependidikan lainnya. Pada akhirnya penyusunan manajemen mitigasi bencana di lingkungan kampus menjadi suatu hal yang penting, karena akan berpengaruh terhadap tingkat keselamatan akibat bencana alam bagi warga kampus (BNPB 2008; BNPB 2017; Nazli, 2014).

Dampak bencana di sektor pendidikan mengakibatkan banyak korban jiwa baik peserta didik dan tenaga pendidik, terhentinya proses belajar mengajar, rusaknya sarana dan prasarana sekolah dan hilangnya dokumen sekolah. Proses belajar mengajar diharapkan terus berjalan dalam kondisi apapun dan warga sekolah memiliki kemampuan dan kesiapan dalam menghadapi bencana di sekolah. Oleh sebab itu, diperlukan kesadaran masyarakat mengenai bencana alam, khususnya warga sekolah yang sangat rentan terdampak jika bencana terjadi di saat jam sekolah. Program Satuan Pendidikan Aman Bencana penting diterapkan dalam rangka menumbuhkan budaya sadar bencana sangatlah penting. Perlu pemahaman yang formal dan terstruktur dalam sistem pendidikan nasional. Tanpa pemahaman dalam kesatuan yang utuh dalam bingkai NKRI, disintegrasi adalah ancaman yang selalu membayangi (BNPB 2008; BNPB 2017; Nazli, 2014).

Harus dipahami hal yang sulit dan rumit ketika dalam pelaksanaan, tetapi tetap wajib dilaksanakan bagi pemerintah yang memang mendapat amanah untuk menyelamatkan dan mensejahterakan segenap anak bangsa. Dengan demikian, pendidikan dan pemahaman tentang mitigasi bencana wajib dilakukan sejak dini melalui jalur pendidikan formal dalam muatan kurikulum baku maupun informal dalam program-program pembinaan masyarakat. Faktor penentu tingkat keselamatan akibat bencana alam di sekolah adalah hal kunci untuk diperhatikan mengingat bencana bisa datang kapan saja, siswa yang secara langsung merespon ketika terjadi bencana alam, semisalnya gempa bumi yang terjadi di jam sekolah, kesiapsiagaan melalui pelatihan dan edukasi menjadi hal penting dalam bagian preventif sebelum terjadinya korban di kalangan rentan di sekolah, yaitu siswa (Rahma, 2018; Guha-Sapir et al., 2010; 
Torani, 2019).

Bencana gempa bumi dan letusan gunung api merupakan bencana alam yang tidak mungkin dicegah dari sumbernya. Yang dapat dilakukan adalah pengurangan risiko bencana (PRB) bila bencana terjadi lagi. PRB (Pengurangan Risiko Bencana) adalah serangkaian upaya untuk meminimalisir kerugian saat terjadi bencana khususnya di sekolah. PRB yang sudah mencakup mitigasi dan kesiapsiagaan, adalah bagian dari penyadaran menghadapi ancaman bencana (Pasal 1 ayat 6 PP No. 21 tahun 2008 tentang penanggulangan bencana). Salah satu sub-sistem kesiapsiagaan adalah pembuatan PROTAP (Prosedur Tetap) mengenai bencana di sekolah. Hal ini mutlak adanya, mengingat ketika terjadi bencana terkadang masyarakat sekolah sangat minim pengetahuan tentang apa yang harus mereka lakukan, dan kemana mereka harus menyelamatkan diri ketika bencana terjadi (BNPB 2008; BNPB 2017; Nazli, 2014).

Kampus utama Universitas Jenderal Achmad Yani, terletak di Kampus terletak kawasan militer yaitu di bagian Selatan Kota Cimahi, Jawa Barat tepatnya di Jalan Terusan Jenderal Sudirman. Kota Cimahi sebagai salah satu kota di Jawa Barat hanya berjarak sekitar 5.8 sampai $12 \mathrm{~km}$ dari Patahan Lembang. Kondisi tersebut mengakibatkan Kota Cimahi menjadi salah satu kota dengan risiko terbesar mengalami kerusakan bila terjadi pergerakan patahan Lembang. Menurut kajian Badan Penanggulangan Bencana Daerah (BPBD) Kota Cimahi, berdasarkan potensi kerusakannya, Cimahi bisa terdampak amplifikasi gempa dua kali lebih besar dibanding wilayah lain yang berada di urat sesar. Cimahi berada dalam zona merah bencana Sesar Lembang. Oleh karena itu upaya sosialisasi dan pembinaan mitigasi bencana menjadi salah satu langkah penting yang perlu digalakkan, sebagai upaya pengurangan resiko bencana (Maulana, 2019).

Permasalahan yang dihadapi terkait ketersediaan sistem mitigasi bencana di lingkungan kampus Universitas Jenderal Achmad Yani meliputi lingkungan kampus yang bersih dan tertata rapi dengan penghijauan dan sirkulasi udara yang baik, namun sebagian besar gedung di wilayah kampus belum dilengkapi sistem pengamanan dalam rangka penyelamatan jika terjadi bencana seperti sirine sebagai tanda peringatan, petunjuk arah dan jalur evakuasi, dan titik kumpul. Modul penanganan bencana, papan petunjuk, gambar, poster yang dapat ditempel di masing-masing gedung sebagai media edukasi bagi warga kampus dalam meningkatkan pengetahuan untuk kesiapsiagaan jika terjadi bencana belum tersedia. Pengetahuan warga 
kampus khususnya para tenaga pengajar dan kependidikan dalam kesiapsiagaan menghadapi bencana relatif masih rendah. Oleh karena itu, perlu dilakukan sosialisasi dan pembinaan dalam upaya mencapai tujuan pembangunan sistem mitigasi bencana di lingkungan kampus Unjani, sehingga meningkatkan kewaspadaan warga kampus dan menciptakan Unjani sebagai prototipe kampus yang tanggap dan siaga bencana.

\section{Metode}

Perencanaan, pelaksanaan dan evaluasi program sosialisasi dan simulasi mitigasi bencana bagi para tenaga pengajar, tenaga kependidikan dan penunjang di lingkungan kampus Universitas Jenderal Achmad Yani ini melibatkan dosen, mahasiswa, dan dokter muda di FK Unjani, bekerjasama dengan narasumber yang kompeten dari Badan Nasional Penanggulangan Bencana (BNPB). Masalah prioritas yang akan ditangani dalam program ini disusun bersama antara Tim Pengabdian Masyarakat FK Unjani dengan narasumber dari BNPB. Pelaksanaan program sosialisasi pelatihan ini dilaksanakan selama 3 (tiga) hari berturut-turut, pada tanggal 20 sampai dengan 22 Oktober 2020 dalam 2 tahap, yaitu tahap materi secara online melalui zoom meeting dan tahap simulasi ruang secara offline di kampus FK Unjani.

Kegiatan ini melibatkan warga kampus dari seluruh fakultas dan rektorat di lingkungan Universitas Jenderal Achmad Yani, yang mengirimkan perwakilannya yang terdiri dari dosen, tenaga kependidikan, dan penunjang seperti satpam, tenaga kebersihan dan lain-lain untuk mengikuti kegiatan pelatihan. Dosen, mahasiswa dan dokter muda FK Unjani serta seluruh peserta melakukan kegiatan berupa perumusan rencana kontingensi yang kemudian diaplikasikan dalam kasus untuk kemudian dilakukan simulasi ruang guna menilai kelayakan program dan rencana kontingensi yang disusun sebelumnya. Kegiatan simulasi ruang dilakukan dalam bentuk focus group discussion (FGD), dan didukung dengan buku modul, video simulasi, serta diakhiri dengan evaluasi program.

Setelah pemberian materi dan simulasi dilakukan, peserta dievaluasi dengan memberikan kuesioner untuk menilai apakah terdapat perubahan pola pandang dan sikap dari para peserta terhadap konsep dasar manajemen bencana atau sistem mitigasi bencana. Untuk menilai sikap peserta tentang pentingnya pendidikan dan pelatihan ini, kuesioner mencakup pertanyaan yang menilai sudut pandang peserta mengenai pentingnya topik pendidikan dan pelatihan (diklat) ini dilaksanakan, manfaat kegiatan, kepercayaan diri serta keinginan peserta untuk mengaplikasikan/menerapkannya dalam kehidupan sehari-hari, serta menilai pendapat peserta 
tentang pencapaian tujuan pelatihan dengan harapan dari para peserta. Penilaian terhadap sudut pandang dan sikap peserta ini diajukan dari pertanyaan-pertanyaan tersebut, dengan pilihan jawaban sangat setuju, setuju, ragu-ragu, tidak setuju dan sangat tidak setuju.

\section{Hasil dan Diskusi}

Pelaksanaan kegiatan Pendidikan dan Pelatihan Simulasi Mitigasi Bencana ini dilaksanakan dalam dua sesi, yaitu sesi materi yang dilaksanakan secara online pada hari pertama kegiatan, dan sesi simulasi ruang yang dilaksanakan dua hari berikutnya secara offline. Pada sesi pemberian materi peserta dipaparkan materi dasar manajemen bencana yang disampaikan oleh narasumber dari BNPB. Sesi materi ini diikuti oleh sebanyak 50 orang yang terdiri dari dosen, staf tenaga kependidikan dan penunjang yang merupakan perwakilan dari seluruh unit kerja di lingkungan kampus Unjani dan 10 orang dosen FK Unjani yang membentuk Team Internal yang berfungsi memandu kegiatan simulasi ruang. Sesi materi disampaikan melalui zoom meeting, seperti yang tertera pada Gambar 1.

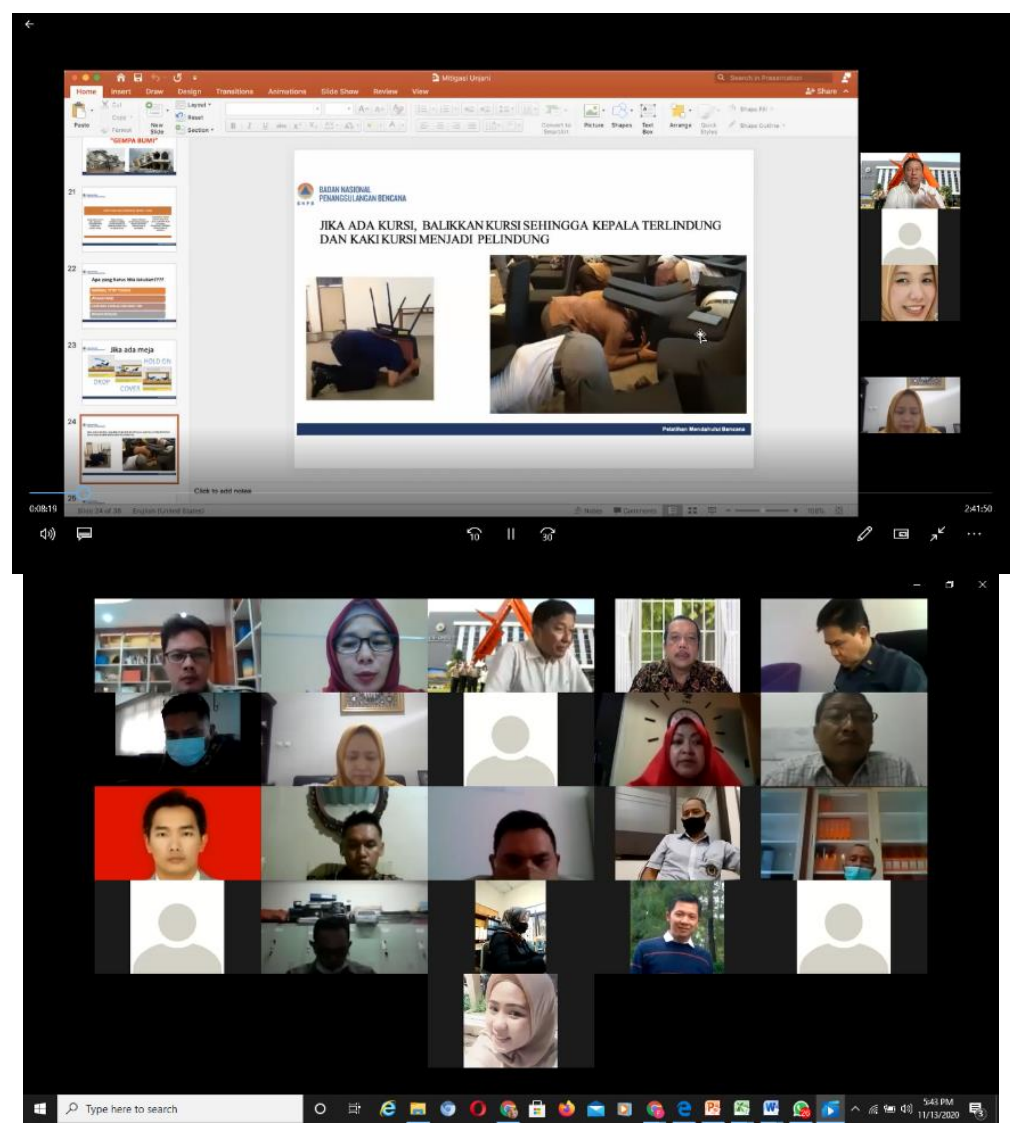

Gambar 1. Sesi Materi Melalui Link Zoom Meeting 
Kegiatan dilanjutkan dengan sesi simulasi ruang yang diikuti sekitar 60 orang peserta yang dibimbing langsung oleh Narasumber dari BNPB dengan bantuan dokter muda FK Unjani seperti tampak pada Gambar 2. Kasus yang disimulasikan berupa kasus gempa bumi, menyesuaikan dengan kondisi geografis kampus Unjani yang kemungkinan besar beresiko terhadap terjadinya bencana gempa bumi.
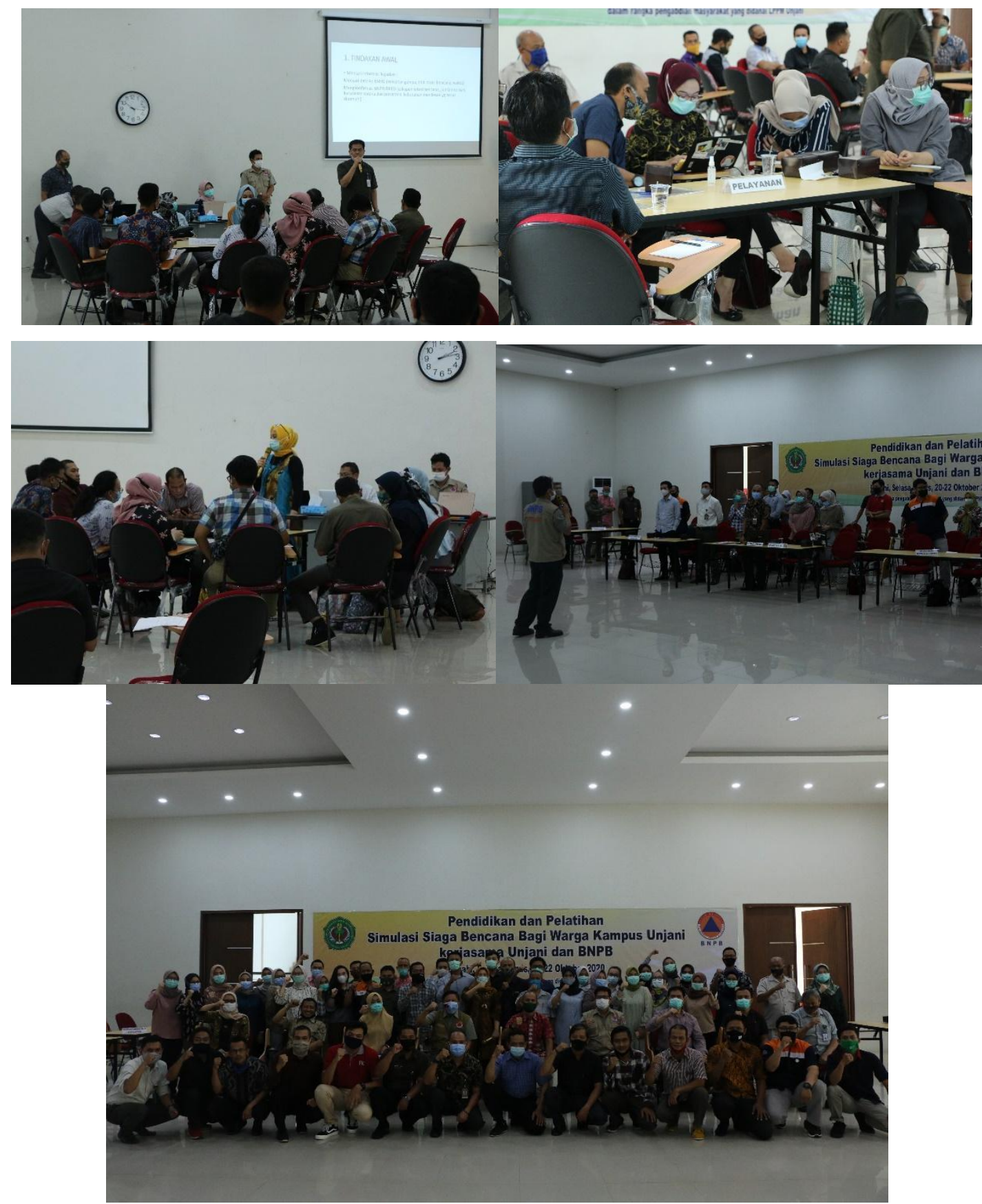

Gambar 2. Kegiatan Simulasi Ruang Mitigasi Bencana

Volume 2, Nomor 2, Oktober 2021|92

Sosialisasi dan Pelatihan Mitigasi Bencana Guna Membangun Universitas Jenderal Achmad Yani sebagai Prototipe Kampus Siaga Bencana 
Berdasarkan perlunya topik pendidikan dan pelatihan yang dilaksanakan, peserta yang menunjukkan sikap sangat setuju sebanyak 42,9\%, setuju sebanyak 39,3\%, dan ragu-ragu sebanyak $14,3 \%$, sebanyak 3,6\% tidak setuju dan $0 \%$ yang menyatakan sangat tidak setuju. Dari aspek manfaat kegiatan pendidikan dan pelatihan ini, sebanyak 57,1\% peserta pelatihan menyatakan sangat setuju, 28,6\% setuju dan sisanya 14,3\% ragu-ragu. Tidak ada yang menyatakan tidak setuju atau sangat tidak setuju bahwa kegiatan ini bermanfaat (0\%). Berdasarkan kepercayaan diri peserta untuk mempraktekkan dan mengaplikasikan pengetahuan tentang mitigasi bencana ini, sebanyak $42,9 \%$ sangat setuju, sebanyak $42,9 \%$ setuju dan sebanyak $14,3 \%$ sisanya ragu-ragu. Peserta yang tidak setuju dan sangat tidak setuju pendidikan dan pelatihan ini meningkatkan kepercayaan dirinya untuk mengaplikasikan pengetahuan tentang mitigasi bencana masing-masing menunjukkan hasil $0 \%$.

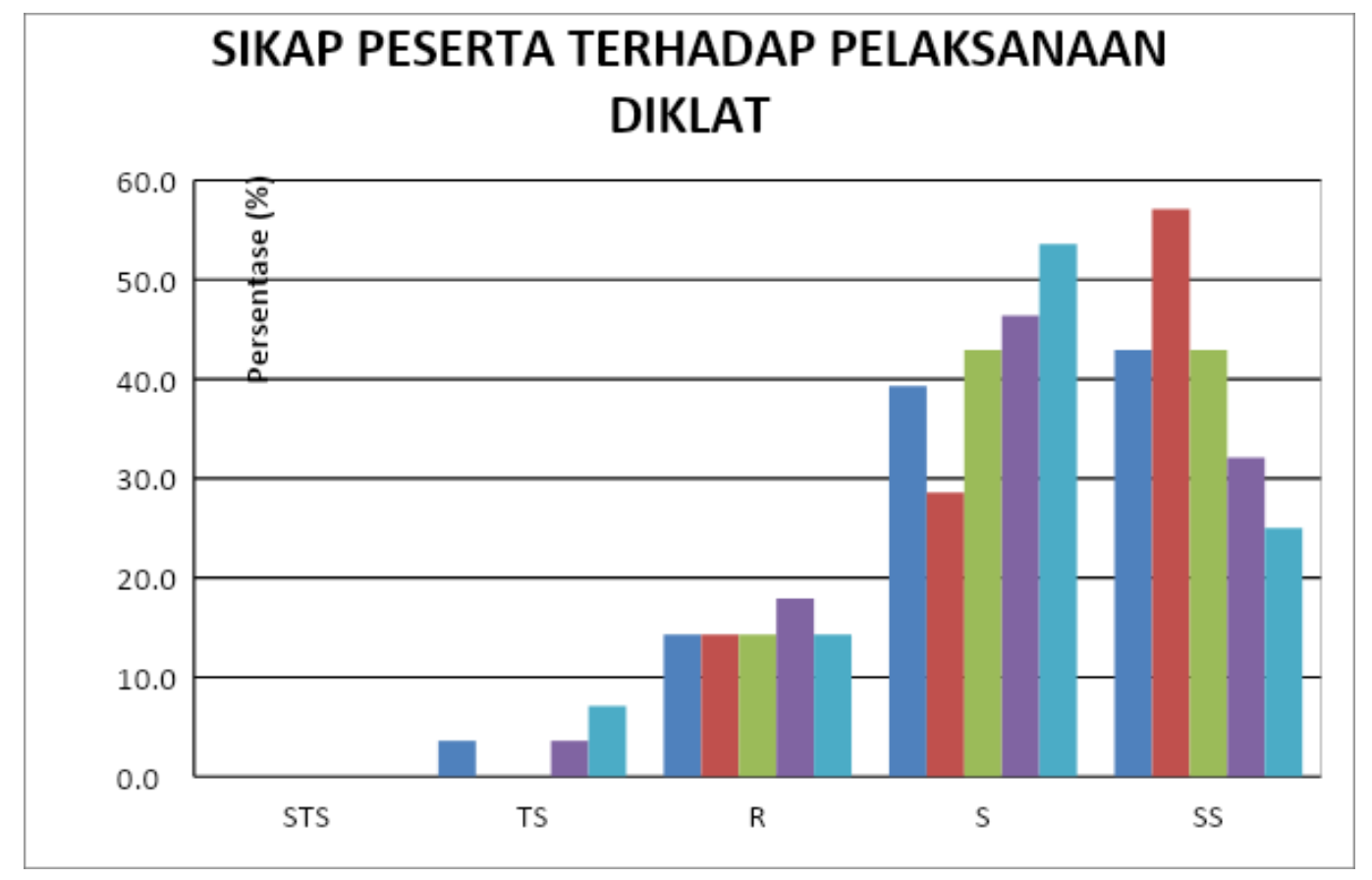

Gambar 3. Sikap Peserta Pelatihan dan Pendidikan Tentang Simulasi Bencana

Sebanyak $32,1 \%$ peserta menyatakan sangat setuju, sebanyak $46,4 \%$ peserta setuju dan 8\% merasa ragu-ragu memiliki kemauan untuk menerapkan pengetahuan tentang mitigasi bencana ini. Berdasarkan persepsi bahwa kegiatan ini sesuai dengan harapan mereka, sebanyak $25 \%$ menyatakan sangat setuju, 53,5\% setuju, $14,3 \%$ ragu-ragu dan sebanyak $7,1 \%$ tidak setuju. Tidak ada yang sangat tidak setuju kegiatan ini bermanfaat. Gambaran sikap peserta terhadap pelaksanaan pendidikan dan pelatihan ini dapat dilihat pada Gambar 3. 
Anak dan remaja usia sekolah sangat rentan terhadap masalah kesehatan dan bencana. Meskipun tanggung jawab utama kesehatan dan keselamatan anak berada di tangan orang tua, kampus dapat berperan dalam mengembangkan perilaku hidup sehat dan kesiapsiagaan bencana sejak dini. Hal ini dikarenakan siswa biasanya patuh pada aturan dan perintah guru atau dosen. Oleh karena itu siswa sekolah harus dibiasakan untuk berperilaku sehat dan dapat dilatih pada saat bencana, melalui kegiatan pembelajaran di kelas dan dilaksanakan langsung dalam kehidupan sehari-hari. Pembiasaan ini diharapkan mampu membangun karakter dan perilaku peduli kesehatan dan keselamatan diri serta lingkungan, sehingga diharapkan mampu menularkan kemampuannya kepada orang-orang di sekitarnya. Pada akhirnya berdampak pada peningkatan kualitas masyarakat. Pendidikan dan pelatihan meningkatkan pengetahuan masyarakat tentang penanggulangan bencana. Pelatihan memiliki efektivitas dalam meningkatkan kinerja peserta. Memberikan informasi tentang keadaan darurat merupakan bagian penting dari upaya mitigasi bencana (Putera, 2016; BNPN 2008; BNPB 2017).

Kebutuhan individu dan organisasi harus selaras. Program pelatihan dapat mencapai tujuan pelatihan yang dapat dipenuhi oleh kebutuhan organisasi dan individu. Ada beberapa masalah yang dihadapi dalam melaksanakan pelatihan kesiapsiagaan bencana seperti kurangnya dana dalam pelatihan, kurangnya dukungan, kurangnya kesadaran di kalangan masyarakat dan lebih fokus pada pelatihan untuk pengembangan pekerjaan, terbukti dari data evaluasi yang diperoleh masih terdapat 3,6 \% yang berpendapat bahwa topik pendidikan dan pelatihan mengenai mitigasi bencana ini tidak menarik dan tidak bermanfaat. Badan Nasional Penanggulangan Bencana adalah badan yang membantu melaksanakan berbagai program untuk meningkatkan kesadaran penanggulangan bencana banjir, yang akan membuat masyarakat umum lebih sadar dan selalu terinformasi, serta juga siap menghadapi bencana di masa depan. Melalui bantuan berbagai pihak, diharapkan program pelatihan dapat lebih digalakkan dan mampu mencerdaskan masyarakat dari segala usia (Nazli, 2014).

\section{Kesimpulan}

Pelaksanaan kegiatan sosialisasi dan pelatihan mitigasi bencana bagi warga kampus Unjani telah terealisasi dan berdasarkan hasil evaluasi sebagian besar peserta memiliki pandangan dan sikap yang positif terhadap pentingnya kegiatan pendidikan dan pelatihan tentang dasar manajemen bencana, sebagai langkah awal untuk membangun sistem mitigasi 
bencana di lingkungan kampus Unjani.

Untuk membentuk perilaku tanggap dan siaga bencana, perlu dilakukan pembiasaan agar terbangun karakter dan perilaku peduli kesehatan dan keselamatan diri serta lingkungan, sehingga diharapkan mampu menularkan kemampuannya kepada masyarakat di sekitarnya. Harapan selanjutnya agar pengetahuan dan kemampuan para peserta dapat diimplementasikan di lingkungan kampus, dengan pembentukan satgas bencana dan mengembangkan sistem mitigasi bencana yang semakin mapan guna mewujudkan Unjani sebagai kampus siaga bencana.

\section{Ucapan Terima Kasih}

Ucapan terima kasih disampaikan kepada berbagai pihak yang telah mendukung dan terlibat aktif dalam kegiatan pengabdian kepada masyarakat yaitu Rektor Unjani, Kepala Pusat Pendidikan dan Pelatihan Badan Nasional Penanggulangan Bencana, Ketua LPPM Unjani, Dekan Fakultas Kedokteran Unjani, para Dekan Fakultas dan Kepala Unit Kerja di lingkungan Unjani, dan para staf pengajar dosen dan non dosen, dokter muda, mahasiswa dari Fakultas Kedokteran Unjani.

\section{Daftar Referensi}

BNPB. Peraturan Kepala Badan Nasional Penanggulangan Bencana Nomor 4 Tahun 2008 Tentang Pedoman Penyusunan Rencana Penanggulangan Bencana. Badan Nasional Penanggulangan Bencana 2008.

BNPB. Buku Saku Tanggap Tangkas Tangguh Menghadapi bencana. Badan Nasional Penanggulangan Bencana. 2017

BNPB. Buku Pedoman Latihan Kesiapsiagaan Bencana. Membangun Kesadaran, Kewaspadaan dan Kesiapsiagaan dalam Menghadapi Bencana. Badan Nasional Penanggulangan Bencana. 2017

Guha-Sapir, D., Hoyois, P., Wallemacq, P. \& Below, R. 2016. Annual Disaster Statistical Review 2016: The Numbers and Trends, Center For Research on The Epidemiology of Disaster (CRED).

Guha-Sapir, D., Vos, F., Below, R. \& Ponserre, S. 2010. Annual Disaster Statistical Review. Center for Research on The Epidemiology of Disaster, Ciaco Imprimerie, Belgia. 
Maulana, Y. 2019. Kota Cimahi Masuk Zona Merah Potensi Kerusakan Sesar Lembang. Diakses tanggal 16 Oktober 2019 dari laman https://news.detik.com/berita-jawabarat/d-4747973/kota-cimahi-masuk-zona-merah-potensi-kerusakan-sesar-lembang

Nazli, N., Sipon, S., Radzi, H.M. 2014. Analysis of training in disaster preparedness. Procedia - Social and Behavioral Science 140, 576-580.

Putera, R.E., Nurasa, H. \& Sugandi, Y.S. 2016. Synergizing stakeholders in reducing risk of earthquake and tsunami disaster in most vulnerable area. International Journal of Administrative Science \& Organization, 23, 147-55.

Rahma, A. 2018. Implementasi Program Pengurangan Risiko Bencana (PRB) Melalui Pendidikan Formal. Varia Pendidikan, 30(1), 1-11.

Torani, S., Madj P.M., Maroufi, S.S., Dowlati, M., Sheiki, R.A. 2019 The importance of education on disasters and emergencies: a review article, J Educ Health Promot, $8(85)$.

Wisner, B., Blaikie, P., Cannon, T. \& Davis, I. 2005. At Risk: natural hazard, people's vulnerability and disaster. Journal of Homeland Security and Emergency Management, 2(1). 